\title{
Direitos e Vantagens do Funcionário
}

\section{Corsíndio Monteiro da Silva}

I - Vencimento ou remuneração. Cotas ou percentagens.

II - Tempo de Serviço. Ajuda de Custo. Diárias.

III - Auxilio para diferença de caixa. Auxilio-doença. O instituto das gratificaçôes. Gratificação de função. Gratificação pelo exercício de magistério. Gratificação pelo exercicio em determinadas zonas ou locais. Gratificação pela prestação de serviço extraordinátio.

IV - Gratificação pela representação de Gabinete. Gratificaఢ̧ão por serviço ou estudo no estrangeiro. Gratificação pela participação em órgão de deliberação coletiva. Gratificação pelo en. cargo de auxiliar ou professor de cursos legalmente instituidos. Gratificação adicional por tempo de serviço. Gratificação por hora de vôo.

A

contraprestação do serviço é de suma importância na vida funcional. $\hat{E}$ aquilo que se vai ganhar que atrai para o cargo público! E' a remuneração, o salário, o vencimento que condiciona a função, o emprêgo, o cargo e até mesmo concorre para aquilatar-lhe o grau de responsabilidade ou situá-lo hieràrquicamente.

É postulado estatutário a vedação de prestação de serviços gratuitos, e um dos elementos que concorrem para a conceituação de cargo público é ser o seu ocupante pago pelos cofres da União.

Assim, pelo efetivo exercício do cargo, o funcionário percebe uma retribuição em dinheiro, paga periòdicamente pelos cofres públicos. A obrigação do pagamento vence mês a mês. Cada fim de mês dá-se o vencimento do prazo para o pagamento que se faz parcelado.

Primitivamente, atribuia-se ao servidor um vencimento anual. não raro fazendo, o ato de nomeação, menção, não só ao cargo que estava sendo provido, como à quantia anual que o nomeado venceria. A despeito disso, o pagamento era efetuado parcelada 
mente e a data do vencimento acabou por coincidir com o último dia do mês.

Hoje, a retribuição do cargo corresponde a um mês de trabalho, quando se dá o vencimento. E esta palavra designa essa remuneração que se faz mês a mês.

Vencimento no singular, porque está a indicar a unidade convencionada e assim denominada. Não há por que dizer: "Quantos são os seus vencimentos?" O padrão que a lei fixa corresponde a uma unidade, a uma retribuição mensal a que se deu o nome de vencimento.

Hoje, as expressões vencimento e remuneração cristalizaram-se e cada qual passou a ter o seu próprio significado: Vencimento, segundo o Estatuto dos Funcionários, é a retribuição pelo efetivo exercicio do cargo, correspondente ao padrão fixado em lei. Já remuneração é a retribuição paga ao funcionário pelo efetivo exercicio do cargo, correspondente a dois terços do padrão do vencimento e mais as cotas ou percentagens atribuidas em lei.

- Quem tem vencimento?

- Em princípio, qualquer um funcionário público.

- E remuneração?

- Determinados funcionários, como os Agentes Fiscais do Impôsto de Renda, os Agentes Fiscais do Impôsto de Consumo, os Diplomatas... Por exemplo, um ocupante de cargo isolado de provimento efetivo, no exterior, terá sua remuneração correspondente ao vencimento do cargo acrescido de representação no Brasil. Os agentes fiscais, sua remuneração corresponde a dois terços do padrão do vencimento do cargo mais as cotas ou percentagens.

- Há uma limitação para a remuneração?

- Sim! Em razão, principalmente, das excessivas vantagens que tinham certas categorias funcionais, como as dos Agentes Fiscais, começou a legislação a determinar um limite máximo de estipêndio. Atualmente é o Decreto-lei $n^{\circ} 81$, de 21 de dezembro de 1966 , que, em seu artigo 35 , com a redação dada pelo Decreto-lei $\mathrm{n}^{\circ} 177$, de 16 de fevereiro de 1967, estabelece que "os servidores públicos civis e militares, ativos e inativos, da Administração Centralizada e das Autarquias, não poderão receber, no País, mensalmente, dos cofres públicos, importância superior a $90 \%$ dos vencimentos fixados para os Ministros de Estado."

- E dêsse teto nada se excluiu?

- Sim! Quanto aos funcionários civis, estão excluídos do teto as seguintes vantagens: salário-família, gratificação adicional por 
tempo de serviço, gratificação pela participação em órgão de deliberação coletiva, diárias e ajuda de custo previstas no Estatuto dos Funcionários.

- E como ficam os que exercem dois cargos em regime de acumulação?

- Verificarse o teto em cada um dos cargos ocupados e, não, em ambos.

- Quem acumula, sempre levando vantagem...

- Realmente! O legislador deveria proceder como fazem outros povos mais adiantados! A regra é, também, de proibição de acumular, em princípio! Nas exceções, ainda se põe uma limitação nos vencimentos! Nunca se paga cem por cento do vencimento em cada cargo acumulado, porque, verdadeiramente, quem acumula dificilmente desempenha bem ambos os dois cargos. Aliás, diga-se de passagem, nossos legisladores sempre encorajaram os acumuladores de cargos, desestimulando, talvez até inconscientemente, os que se dedicam ao desempenho de um só cargo. Quem acumula, dificilmente, por um só cargo, chega ao teto! Quem não acumula, não raro atinge o teto, porque freqüentemente está no regime de tempo integral e dedicação exclusiva! E a gratificação correspondente faz ultrapassar quase sempre o estipêndio... Então, a alfanje do teto corta o que ultrapassa, ainda que seja em decorrência de uma gratificação por dedicação exclusiva...

- Um absurdo...

- Demagogia! Falta de sensibilidade e de visão dos problemas! Dá-se com a mão direita e tira-se com a esquerda... O razoável seria pagar -se cem por cento por um dos cargos acumulados c setenta por cento por outro! sistema?

- De acôrdo! O pagamento de vencimento obedece a algum

- Sim! Conforme a Lei n? 3.780, de 12 de julho de 1960 , o vencimento corresponde a determinado nível, que varia de 1 a 18 . Após o advento dessa Lei de Classificação de Cargos, mais quatro níveis foram instituídos, até o nivel $22 \ldots$

- Por que?

- Para retribuir os cargos de nível universitário - Médicos, Agrônomos, Engenheiros, Assistentes Sociais, Técnico de Administração etc.

- Como são classificados êsses cargos? 
- De acôrdo com a duração dos respectivos cursos universitários. Engenheiro e Médico, por exemplo, que têm currículo de formação universitária de cinco ou seis anos respectivamente, tiveram seus respectivos cargos classificados nos niveis 21 e 22 .

- E o Economista, cujo currículo é menor?

- O Economista, tanto quanto o Contador, tem um currículo de quatro anos! Estão classificados nos níveis 20, 21 e 22 .

- E o cargo de Bibliotecário?

- Está clåssificado nos níveis 19 e 20, porque o currículo de sua formação universitária, tanto quanto o de Documentarista, é de três anos.

- Os cargos privativos dos bacharéis em Direito que têm currículo de cinco anos estão classificados em que níveis?

- São cargos fora do Sistema de Classificação. Na Administração Indireta, temos os Procuradores escalonados em três categorias - Procuradores de terceira categoria (inicial), Procuradores de segunda categoria e Procuradores de primeira categoria, subordinados a um Procurador-Geral. Na Administração Direta, temos os Assistentes Juridicos e os Consultores Jurídicos, que integram o Serviço Jurídico da União, enquanto os Procuradores da República integram o Ministério Público. Têm êles uma retribuição especial.

- Não parece injusto que um Procurador ou Assistente Jurídico tenha um tratamento especial quanto à retribuição, enquanto o Médico ou o Engenheiro, profissionais do mesmo nivel, ganham muito menos?

- A injustiça é mais aparente que real! Um jovem Engenheiro, por exemplo, ingressa no Serviço Público, ao mesmo tempo que um Bacharel em Direito, êste como Procurador autárquico de terceira categoria. Ambos se adestram no seu ofício, o Procurador com uma dificuldade sensivelmente maior, dada a natureza do seu trabalho, a sedimentação de conhecimentos que deve possuir, o trato permanente dos livros, da jurisprudência administrativa e dos Tribunais, a se preparar na luta que, permanentemente, deve travar no interêsse da Administração, do Estado, do Erário! ( Engenheiro aperfeiçoará o seu ofício no desempenho do cargo, com as suas atribuições específicas, definidas, e, em seu escritório, ou numa organização integrada por Engenheiros, poderá, tranqüilamente, aplicar os conhecimentos que adquiriu ou que aperfeiçoou, ganhando dinheiro com isso. Nada há que impeça ao Engenheiro do Serviço Público exercer seu ofício lá fora em tôda a 
sua plenitude! Mas isso não acontece com o Bacharel em Direito que com êle ingressou no Serṽiço Público, como Procurador autárquico! O Procurador, diligente, estudioso, dedicado a seu ofício, também aprende ou aperfeiçoa seus conhecimentos no desempenho de suas atribuições específicas, tanto quanto o Engenheiro, porém, ao contrário do que acontece com êste, não poderá exercer seu ofício lá fora em tôda a sua plenitude! O Assistente Jurídico, por exemplo, muito aprende Direito Administrativo, legislação de pessoal etc., distanciando-se, quase sempre, dos outros ramos do Direito. Pois bem, o Assistente Jurídico, ao contrário do Engenheiro ou do Médico, não poderá aplicar o conhecimento que adquiriu no desempenho de seu cargo no exercício da advocacia. Só poderá advogar em matéria de Direito Privado e nunca contra a União! Nem mesmo poderá responder às consultas ou dar pareceres que versem assunto relacionado com o conhecimento que adquiriu no trato da coisa pública! Só depois de aposentado, assim mesmo dois anos depois!

\section{- E o Médico?}

- Um Médico, por exemplo, adestra-se, exercita-se, aperfeiçoa-se no Hospital dos Servidores do Estado, ganha até fama numa especialização. Que é que o impede de exercer, tranqüilamente, sua profissão em sua clínica particular? De aplicar, no hospital em que trabalha, a especialidade que adquiriu no Hospital dos Servidores do Estado?

- E ainda pode acumular?

- Exatamente! E ainda pode exercer dois cargos iguais de Médico no Serviço Público, sob o fundamento de carência de assistência médica que, com acumulação ou sem acumulação, continua na mesma... Ac̣umulam dois cargos públicos iguais e ainda trabalham em sua clinica particular...

E o Procurador, o Assistente Jurídico, o Consultor Jurídico? Só podem advogar - quando podem - em assunto fora de sua especialização adquirida no Serviço Público, ou, então, ser Professor de Direito, para ganhar uma ridicularia... Não há sòmente casos de impedimento, que é de proibição parcial, mas, também, de incompatibilidade, que implica em proibição total de exercício da advocacia, até mesmo em causa própria.

- Quando há aumento do salário-mínimo, a escala de vencimento do funcionário sofre alguma alteração?

- Sim! Sòmente até o nível que corresponder ao maior salário-minimo. Por exemplo, os niveis 1 e 2 correspondiam a 
NCr\$ $\$ 1,50$ e $\mathrm{NCr} \$ 99,00$ mensais, enquanto o maior saláriominimo era $\mathrm{NCr} \$ 105,00$.

Pois bem, os ocupantes de cargos situados nesses níveis, além dos respectivos vencimentos, percebiam a diferença entre o ven cimento e o valor do maior salário-mínimo, a título de gratificação complementar!

- Quer dizer que os ocupantes de cargos classificados nos niveis 1 e 2 têm verdadeira antecipação de aumento de vencimento?

- Realmente, o que não impede de reclamarem quando vem o aumento para seus colegas do Serviço Público...

- Quando há aumento de vencimentos dos funcionários pủblicos, como se faz o cálculo do percentual?

- Calcula-se sôbre o vencimento correspondente ao nível do cargo ocupado pelo funcionário e não sôbre o vencimento acrescido da gratificação complementar.

- O funcionário investido em cargo em comissão deixará de perceber o vencimento de seu cargo efetivo?

- Sim, passando a perceber o valor do símbolo do cargo em comissão por êle ocupado, salvo se optar pelo vencimento do cargo efetivo. Neste caso, perceberá, além dêsse vencimento, mais a gratificação de $20 \%$ do valor do símbolo de vencimento do cargo em comissão em cujo exercício estiver.

- O mesmo poderá ocorrer com referência a ocupante de função gratificada?

- Sim.

- Quando há perda de vencimento ou remuneração do cargo efetivo?

- Quando o funcionário fôr nomeado para cargo de provimento em comissão; quando o funcionário estiver no desempenho de mandato eletivo remunerado, federal, estadual ou municipal; quando o funcionário fôr designado para servir em autarquia, socieclade de economia mista ou estabelecimento de serviço público, e quando tiver decretada sua prisão administrativa e enquanto ela perdurar.

- O funcionário ocupante de cargo técnico ou científico, colocado à disposição de Govêrno estadual ou da Prefeitura do Distrito Federal, para exercer cargo ou função em comissão relacionado com o cargo de que é titular, ser-lhe-á lícito optar pelo vencimento ou remuneração do cargo federal... 
- Realmente, sem prejuízo da gratificação concedida pelo Govêrno estadual ou municipal!

- Se, por qualquer circunstância, o funcionário deixar de comparecer ao serviço?

- Perderá o vencimento ou remuneração correspondente ao dia em que deixar de comparecer, a menos que o seja por motivo previsto em lei ou doença comprovada.

- Bem! E ai é que serão relevadas até três faltas, no período de um mês, em razão de doença atestada oficialmente!

- Exatamente! Mas há, ainda, o caso de comparecimento tardio ou saída antes de findo o expediente! Ai, o funcionário perderá um têrço do seu vencimento ou da remuneração diária. Esclareça-se que comparecimento tardio é aquêle ocorrido dentro da hora seguinte à do expediente, porque se o funcionário chegar na segunda hora do expediente já perderá todo o vencimento do dia.

- O caso de prisão, também?

- Sim! O funcionário perderá um têrço do vencimento ou remuneração durante o afastamento em virtude de prisão preventiva, pronúncia por crime comum ou denúncia por crime funcional, bem como em razão de condenação por crime inafiançável єm processo no qual não haja pronúncia...

- Mas, pode ser que seja absolvido...

- Sim, se o fôr, terá direito à diferença. Perderá, ainda, o funcionário dois terços do vencimento ou remuneração, enquanto perdurar o afastamento em virtude de condenação, por sentença definitiva, a pena que não determine demissão ou perda do cargo.

- Se um funcionário, ao observar seu contra-cheque, notar que the foi creditada importância maior do que a que lhe é legalmente devida! Como deverá proceder?

- Deverá requerer a reposição da importância, que poderá ser feita de uma só vez, se assim o entender o funcionário, ou parceladamente...

- Parcelas mensais?

- Sim, não excedentes da décima parte do vencimento ou remuneração.

- Mas, e se o funcionário exonerar-se nesse meio tempo?

- O desconto será feito de uma sỏ vez, o mesmo acontecendo se incorrer em abandono do cargo. 
Cumpre notar, por fim, que o vencimento, remuneração ou quaisquer vantagens pecuniárias atribuídas ao funcionário não podem ser objeto de arresto, seqüestro ou penhora, medidas judiciais, salvo se para garantir prestação alimentar ou quando se trate de divida à Fazenda Nacional.

Diz o artigo 120 do Estatuto dos Funcionários que "remuneração é a retribuição paga ao funcionário pelo efetivo exercícis do cargo, correspondente a dois terços do padrão do vencimento e mais as cotas ou percentagens atribuidas em lei."

O artigo 152 daquele mesmo diploma legal assim dispõe: "As cotas partes de multa ou percentagem serão fixadas em lei, tornando-se sòmente devidas após o julgamento definitivo e irrecorrivel do processo de infração."

- Essa vantagem é devida a qualquer funcionário?

- Sempre se entendeu ser ela devida somente aos que desempenhassem realmente funções de fiscalização, tais como os servidores do Impôsto de Renda, os Agentes Fiscais do Impôsto de Consumo, os que servissem nas Recebedorias, nas Alfândegas... O regime de que gozavam decorria do que dispunham o Decreto $\mathrm{n}^{\circ} 22.717$, de 16 de maio de 1933; o Decreto $\mathrm{n}^{\circ} 24.343$, de 5 de junho de 1934; o Decreto-lei n' 5.844, de 23 de setembro de 1943 - Consolidação das Leis do Impôsto de Consumo; o Decreto $n^{\circ}$ 38.736, de 30 de janeiro de 1956; a Lei $n^{\circ} 3.244$, de 14 de agôsto de 1957 - Lei de Tarifas Alfandegárias; o Decreto número 43.717, de 19 de maio de 1958, que regulamentou a concessão da percentagem prevista na Lei $n^{\circ} 3.244$, de 1957; a Lei $\mathrm{n}^{\circ} 3.470$, de 28 de novembro de 1958; o Decreto $\mathrm{n}^{\circ} 45.422$, de 12 de fevereiro de 1959, que fixou remuneração dos Agentes Fiscais do Impôsto de Consumo; a Lei n 3.756 , de 20 de abril de 1960 - artigos 8? e 9\%; o Decreto n 48.656, de 3 de agôsto de 1960 , que regulamentou aquêles dispositivos da Lei nò 3.756, de 1960; o Decreto $\mathrm{n}^{\circ} 50.642$, de 20 de maio de 1961, que aprovou as novas razões percentuais para efeito de cálculo da parte variável da remuneração dos Agentes Fiscais do Impôsto de Consumo; a Lei $n^{\circ} 4.069$, de 11 de junho de 1962, que alterou a legislação do Impôsto de Renda, estabeleceu forma de participação e fixou um teto de quarenta por cento sôbre cotas-partes; a Lei $n^{\circ} 4.345$, de 26 de junho de 1964 - artigo 14; a Lei n 4.863, de 29 de novembro de 1965 - Fundos de Estímulo; o Decreto n ${ }^{\circ} 59.575$, de 18 de novembro de 1966, que regulamentou o artigo 23 da Lei $n^{\circ} 4.863$, de 1965 , que criou os Fundos de Estímulo; o Decreto $n^{\circ} 57.877$, de 28 de fevereiro de 1966, que regulamentou a aplicação do regime de remuneração aos funcionários ocupantes 
de cargos integrantes do Grupo Ocupacional AF-300 Fisco; o Decreto-lei $n^{\circ} 37$, de 18 de novembro de 1966 - artigo 115 , e, finalmente, o Decreto-lei $n^{\circ} 147$, de 3 de fevereiro de 1967 artigo 32 , parágrafo 6 ?

Com o advento do Decretorlei $n^{\circ} 200$, de 25 de fevereiro de 1967, ficou estabelecido que a adjudicação de cota-parte de multas será feita exclusivamente aos Agentes Fiscais de Rendas Internas, aos Agentes Fiscais do Impôsto de Renda, aos Agentes Fiscais do Impôsto Aduaneiro, aos Fiscais Auxiliares de Impostos Internos e Guardas Aduaneiros, e sòmente quando hajam êles exercido ação direta, imediata e pessoal na obtenção de elementos destinados à instauração de autos de infração ou início de pro cessos para a cobrança dos débitos respectivos. excluídos?

- E os Agentes Fiscais do Impôsto de Consumo ficaram

- Não! São êles os atuais Agentes Fiscais de Rendas Internas.

- A legislação que disciplinava o assunto era copiosa..

- Com efeito, sendo de notar que o Decreto-lei $n^{2} 200$, de 25 de fevereiro de 1967, revogou a Lei $\mathrm{n}^{\circ}$ 3.244, de 1957; a Lei $n^{\circ} 3.470$, de 1958; a Lei $n^{\circ} 3.756$, de 1960, e o Decreto-lei $\mathrm{n}^{\circ} 147$, de 1967, na parte referente ao assunto.

Tenhamos uma idéia aproximada dêsse regime de remuneração. Tomemos o Decreto $n^{\circ} 45.422$, de 12 de fevereiro de 1959, que fixou remuneração dos antigos Agentes Fiscais do Impôsto de Consumo...

- Constituída de uma parte fixa e outra variável...

- Exatamente! Eșsa parte variável era a resultante da percentagem, de que havia uma tabela. A revisão dessa tabela, de conformidade com aquêle decreto, era promovida bienalmente, mediante proposta da Diretoria das Rendas Internas, de modo que as razões percentuais, atribuídas àqueles Agentes Fiscais no biênio anterior, fôssem reduzidas na mesma proporção em que se tivesse verificado o aumento da arrecadação entre os dois anos do mesmo biênio...

- Como se fixavam essas razões percentuais?

- Dividindo-se a arrecadação verificada no primeiro ano do biênio pela arrecadação apurada no segundo, e multiplicando-se o resultado pela razão percentual vigente!

- E as percentagens, como eram elas calculadas? 
- Mensalmente, em cada categoria, sôbre o total do impôsto de consumo arrecadado nos Estados que a compóem. A cada um dos servidores se pagava o quociente da divisão total da percentagem assim calculada, pelo número de Agentes Fiscais lotados nos mesmos Estados.

- E quanto aos demais funcionários fazendários?

- E'-lhes distribuída percentagem proporcional aos respectivos vencimentos. De acôrdo com a Lei n $\mathrm{n}^{\circ} .244$, de 14 de agôsto de 1957, a Lei de Tarifas Alfandegárias, a cota mensal não podia ser superior a cem por cento dos vencimentos. Já a Lei n' 4.345, de 26 de junho de 1964 , em seu artigo 14, determinou continuassem a ser pagos aos funcionários as percentagens sôbre a arrecadação de tributos de rendas federais até os valôres correspondentes à média das importâncias percebidas nos primeiros cinco meses de 1964, sem que pudessem exceder a quarenta por cento do valor do vencimento fixado por aquêle diploma legal para o respectivo cargo efetivo...

- Se a Lei n 4.345 fêz referência a quarenta por cento do valor do vencimento, como ficaram os que percebiam remuneração?

- A própria Lei n: 4.345, de 1964 , esclareceu que os funcionários sujeitos ao regime de remuneração não teriam direito àquelas percentagens, de igual modo como a elas não teriam direito os que ingressassem no Ministério da Fazenda posteriormente à vigência daquele diploma legal, salvo os nomeados mediante concurso, mantido o direito dos que já gozavam da vantagem. É de notar que. posteriormente a essa Lei n? 4.345, houve proposta do Ministério da Fazenda no sentido de que fôsse estendido, aos funcionários que ingressassem no seu Quadro de Pessoal após o advento daquele diploma legal, o direito à vantagem prevista em seu artigo $14 \ldots$

- Prosperou?

- O Presidente da República aprovou Exposição de Motivos do DASP no sentido da rejeição da proposta, ficando esclarecido que o assunto estava superado pela Reforma Administrativa "que virá suprimir o regime que ora se pretende ampliar, resguardando, apenas, os direitos adquiridos."

- Como está regulada a participação nas multas?

- A participação dos funcionários nas multas impostas aos contribuintes em razão de processo instaurado após a vigência da Lei $n^{\circ} 4.069$, de 11 de junho de 1962, é a seguinte: nos casos de infraçăo de simples dispositivos regulamentares, sem falta de 
pagamento de impôsto, vinte e cinco por cento; nos casos de infração que consista em falta de pagamento de impôsto no todo ou em parte, quarenta por cento... Cumpre observar, nesse sentido, o que dispõe o Decreto $n^{\circ} 59.575$, de 18 de novembro de 1966, que regulamentou a aplicação do artigo 23 , da Lei $n^{2} 4.863$, de 29 de novembro de 1965 . Esse decreto regulamentou a adjudicação das vantagens previstas naquele dispositivo, estabelecendo a percentagem que será deduzida do respectivo montante para constituição do fundo de estímulo de que trata a Lei $\mathrm{n}^{\circ}$ 154, de 25 de novembro de 1947, bem como de outros estímulos análogos aos demais órgãos tributários e do Departamento de Arrecadação do Ministério da Fazenda...

- E no caso de leilão?

- Nos casos de importâncias arrecadadas em virtude de leilão de mercadorias, a participação dos funcionários fazendários será de trinta e cinco por cento.

- Quando será paga a percentagem?

- A cota parte de multa só será exigivel quando inteiramente findo o processo de infração. Enquanto houver possibilidade de recurso administrativo, a cota-parte de multa não será adjudicada.

- Tôda essa legislação referida está revogada?

- O assunto, agora, está disciplinado nos artigos 104 e 105 do Decreto-lei $n^{\circ} 200$, de 25 de fevereiro de 1967, que estabelece diretrizes para a Reforma Administrativa. Determina êsse Decreto-lei que ficam extintas a participação, através do Fundo de Estimulo, bem como as percentagens a que se referem o artigo 64 da Lei $n^{\circ}$ 3.244, de 1957; o artigo 109 da Lei $n^{\circ}$ 3.470, de 1958; os artigos $8^{\circ}$, parágrafo segundo, e $9^{\circ}$ da Lei $n^{\circ} 3.756$, de 1960 , e o parágrafo $6 \%$ do artigo 32 do Decreto-lei n: 147 , de 3 de fevereiro de 1967. Faz-se mister notar que, de conformidade com o disposto no artigo 12 da Lei n? 5.421 , de 25 de abril de 1968 , - artigo 32 e seus parágrafos primeiro a quinto do Decreto-lei n? 147 , de 3 de fevereiro de 1967, foi revigorado, e revogado o item IV do artigo 104 do Decreto-lei n²00, de 25 de fevereiro de 1967, cessando a aplicação do disposto no artigo 105 dêsse Decreto-lei aos Procuradores da Fazenda Nacional.

Já dissemos a quem será feita a adjudicação de cota-parte de multas, ressalvados os direitos dos denunciantes...

- Exclusivamente aos Agentes Fiscais de Rendas Internas, àos Agentes Fiscais do Impôsto de Renda, aos Agentes Fiscais 
do Impôsto Aduaneiro, aos Fiscais Auxiliares de Impostos Internos e Guardas Aduaneiros...

- E sòmente quando hajam êles exercido ação direta, imediata e pessoal na obtenção de elementos destinados à instauração de autos de infração ou início de processo para cobrança dos respectivos débitos.

- Quer dizer que aquêle regime de remuneração previsto no artigo 120 do Estatuto dos Funcionários está extinto!

- Não! Continuará a ser aplicado, embora exclusivamente aos Agentes Fiscais de Rendas Internas, aos Agentes Fiscais do Impôsto de Renda, aos Agentes Fiscais do Impôsto Aduaneiro, aos Fiscais Auxiliares de Impostos Internos e Guardas Aduaneiros. O que ficou extinto foi o regime de remuneração instituído a favor dos Exatores Federais, dos Auxiliares de Exatorias e Fiéis do Tesouro, bem como a participação - hoje restabelecida - dos Procuradores da Fazenda Nacional na cobrança da Divida Ativa da União, através da taxa paga pelos executados, a participação através do Fundo de Estímulo, além daquelas percentagens referidas na Lei $n^{\circ} 3.244$, de 1957; na Lei $n^{\circ} 3.470$, de 1958; na Lei $n^{\circ}$ 3.756, de 1960 e no Decreto-lei $n^{\circ} 147$, de 3 de fevereiro de 1967. Já vimos que a participação dos Procuradores da Fazenda Nacional na cobrança da Divida Ativa da União, através da taxa paga pelo devedor, foi restabelecida pela Lei nò 5.421 , de 25 de abril de 1968 , revogado, assim, o item IV, do artigo 104, do Decreto-lei n²00, de 1967.

- Sem qualquer ressalva a direitos adquiridos?

- Não! O artigo 105 do Decreto-lei n 200, de 1967, ressalvou a situação daqueles que, na sua data, estivessem no gôzo daquelas vantagens, ficando-lhes assegurado o direito de percebê-las, como diferença mensal, desde que essa diferença não ultrapasse a média mensal que, àquele titulo, receberam durante o ano de 1966, e até que, em razão dos reajustamentos de vencimentos do funcionalismo, o nivel dos vencimentos dos cargos que ocuparem alcance importância correspondente à soma do vencimento básico e da diferença de vencimentos.

Convém insistir que êsse artigo 105 já não tem aplicação quanto aos Procuradores da Fazenda Nacional, cujo regime de participação foi restabelecido inteiramente pela referida Lei número 5.421 , de 1968 , de efeito repristinatório.

- Que é isso?

- Repristinatório é retôrno ao passado, àquilo que já não se encontrava em uso. Virtude repristinatória é aquela de fazer 
voltar ao primitivo estado. In pristinum statum redire. Na terminologia jurídica, lei repristinatória é aquela que, revogando a anterior, restabelece certa regra expressamente derrogada. Esta Lei $\mathrm{n}^{\circ} 5.421$, de 1968 , pode servir de exemplo a êsse tipo de lei. Assim dispõe o seu artigo 12: "Fica revigorado o artigo 32 e seus parágrafos $1^{\circ}$ a $5^{\circ}$ do Decreto-lei $n^{\circ} 147$, de 3 de fevereiro de 1967 , e revogado o item IV do artigo 104 do Decreto-lei número 200, de 1967, cessando a aplicação do disposto no artigo 105 do mesmo decreto-lei aos Procuradores da Fazenda Nacional."

Por derradeiro, cumpre dizer que a matéria dêste capítulo ainda comporta uma regulamentação.

\section{II}

O Estatuto dos Funcionários abre o capitulo que cogita "Dos direitos e vantagens" com o tempo de serviço! Tal a influência que o tempo de serviço exerce na vida funcional! $O$ tempo de serviço concorre para a estabilidade, a promoção, a nomeação por acesso, a aposentadoria...

De acôrdo com o Estatuto dos Funcionários, a apuração do tempo de serviço será feita em dias, devendo o número de dias ser convertido em anos, considerado o ano como de 365 dias.

- E no caso de ano bissexto?

- Norma fixada em parecer do DASP (1), estabelece que "quando se tratar de ano bissexto, o funcionário, desde que não tenha deixado de comparecer ao serviço, por falta ou licença, deverá contar 366 dias de efetivo exercício e não 365. O total dos dias de efetivo exercício será convertido em anos, e, para efeito da conversão, os anos serão sempre considerados como de 365 dias."

Diz o parágrafo 2 , do artigo 78 , do Estatuto que, "feita a conversão, os dias restantes, até 182. não serão computados, arredondando-se para um ano, quando excederem êsse número, nos casos de cálculo para efeito de aposentadoria."

- Êsse arredondamento é só para fins de aposentadoria?

- Exatamente! Não há falar em conversão nem em arredondamento para fins de promoção, o que resultaria em tumulto e injustiça! Para promoção, toma-se o tempo de serviço sempre em dias.

(1) Parecer no Processo $n^{\circ} 21.948-44, D$. O. de 12-3-45. 
- O tempo de serviço só é válido para tempo de serviço realmente prestado?

- Em princípio assim é, mas existem certos afastamentos que valem como exercícios fictos. São afastamentos que a lei considera como de efetivo exercício: por motivo de férias, de casamento, de luto, exercício de outro cargo federal de provimento em comissão, convocação para serviço militar, júri e outros serviços obrigatórios por lei; por motivo de exercício de função ou cargo de govêrno ou administração, em qualquer parte do território nacional, por nomeação do Presidente da República; em virtude de desempenho de função legislativa da União, dos Estados, do Distrito Federal e dos Municipios; em razão de licença especial, de licença à funcionária gestante, de licença ao funcionário acidentado em serviço ou atacado de doença profissional; missão ou estudo no estrangeiro, quando o afastamento houver sido autorizado pelo Presidente da República - agora, por delegação de competência, desde que autorizado pelo Ministro de Estado ou dirigente de órgão integrante da Presidência da República —; em virtude de exercício, em comissão, de cargo de chefia nos serviços dos Estados, Distrito Federal, Municípios ou Territórios. É considerado, ainda, de efetivo exercício o afastamento em virtude de licença, até o limite máximo de dois anos, ao funcionário acometido de moléstia consignada no artigo 104 do Estatuto e outras indicadas em lei: tuberculose ativa, alienação mental, neoplasia maligna, cegueira, lepra, paralisia irreversível e incapacitante, cardiopatia grave, doença de Parkinson, espondiloartrose anquilosante e nefropatia grave. os efeitos?

- Quer dizer que êsses afastamentos são contados para todos

- Sim! Inclusive para promoção.

- E o periodo chamado de trânsito?

- Deve ser considerado, igualmente, como de efetivo exercício, esclarecido que período de trânsito é aquêle estritamente necessário à viagem para a nova sede.

- O funcionário poderá faltar por motivo de doença...

— Sim! Até o máximo de três dias por mês. E êsses dias de ausência em razão de doença comprovada são considerados como de efetivo exercício e, portanto, computados para todos os efeitos.

- Qual o tempo computado para efeito de aposentadoria e disponibilidade? 
-- Segundo o Estatuto, será computado integralmente o tempo de serviço público federal, estadual ou municipal; o periodo de serviço ativo prestado às fôtças armadas, em tempo de paz; o tempo de serviço prestado como extranumerário ou sob qualquer outra forma de admissão, desde que remunerado pelos cofres públicos; o tempo de serviço prestado em autarquia; o periodo de trabalho prestado à instituição de caráter privado que tiver sido transformada em estabelecimento de serviço público, bem como o tempo em que o funcionário estêve em disponibilidade ou aposentado. E' de notar que a Lei $n^{\circ} 3.841$, de 15 de dezembro de 1960, admitiu a contagem reciproca de tempo de serviço prestado à União, às Autarquias, às Sociedades de Economia Mista e às Fundações instituídas pelo Poder Público.

Para efeito, ainda, de aposentadoria, consoante o Parecer n: 66-X, de 30 de junho de 1965 do Consultor-Geral da República, é de se computar o periodo de efetivo exercício de mandato eletivo anterior ao ingresso do funcionário em função ou cargo público, não importando que o mandato haja sido remunerado ou gratuito.

- Tem havido muita liberalidade em matéria de contagem de tempo de serviço!

- Sim, para efeito de aposentadoria principalmente! Há leis especiais que permitem a contagem de determinados períodos de trabalho ou de afastamento de cargo, para efeito de aposentadoria, como, por exemplo, a Lei $n^{\circ} 806$, de 2 de setembro de 1949, quantos aos "servidores públicos da União que estiverem afastados dos seus cargos ou funções por ato do Govêrno Provisório, desde que lhes tenha sido favorável o pronunciamento da Comissão Revisora instituída em decorrência do parágrafo único do artigo 18 das Disposições Transitórias, da Constituição Federal de 16 de julho de 1934"; a Lei $n^{\circ} 1.126$, de 7 de junho de 1950, quanto aos serviços prestados aos "Serviços de Hollerith S. A.", junto às repartiçôes públicas, antes da aquisição da qualidade de servidores públicos; a Lei $n^{\circ} 1.573$, de 13 de março de 1952, quanto aos serviços regularmente prestados ao Serviço Especial de Saúde Pública, instituição filiada à Fundação Rockefeller, entidade de direito privado; a Lei $n^{\circ} 5.328$, de 4 de outubro de 1967, quanto aos que serviam a estabelecimentos de ensino superior, antes da sua federalização por leis especiais.

Segundo parecer do Consultor Jurídico do DASP (2), o tempo de serviço prestado por serventuário da Justiça, ainda que

(2) Parecer no Processo $\mathrm{n}^{\circ} 2.847-49$, D. O. de 2-7-49. 
não remunerado pelos cofres públicos, deve ser computado integralmente para efeito de aposentadoria.

- Não há um preceito legal que veda a prestação de serviços gratuitos?

- Sim! O artigo 49 da Lei $n^{\circ} 1.711$, de 28 de outubro de 1952.

- Estatuto dos Funcionários. Como é que, vedando a lei a prestação de serviços gratuitos, se há de computar o tempo de serviço prestado nessa condição?

- Bem! Em princípio, não deveria ser mesmo contado para nenhum efeito! Mas entendimento em sentido contrário prosperou em virtude do parecer do então Consultor-Geral da República, Dr. Themistocles Brandão Cavalcanti (3), que aduziu que se o artigo 192 da Constituição de 1946 determinou fôsse computado integralmente o tempo de serviço público federal, estadual ou municipal, para efeito de disponibilidade e aposentadoria, não havia por que escusar-se de sua aplicação, pois que o mandamento constitucional era auto-executável ainda que contra a lei. A seguir, o Dr. Clenício da Silva Duarte, Consultor Jurídico do DASP, em parecer (4), entendeu que seria computável o tempo de serviço gratuito para efeito de gratificação adicional, desde que prestado antes da vigência do Estatuto dos Funcionários de 1939 e comprovada por meio hábil a prestação dêsse serviço.

- Há hipótese de se contar tempo em dôbro?

- Sim! Excepcionalmente! Para fins de aposentadoria. Por exemplo: o tempo de serviço prestado às Fôrças Armadas em operações de guerra, seja na qualidade de militar combatente, seja como médico ou enfermeiro, que, em hospital em plena zona de guerra, presta seus serviços profissionais aos feridos em luta; o período de licença especial que o funcionário não houver gozado; o tempo de serviço de funcionário que tomou parte na Expedição Roncador-Xingu, nos tempos da Lei n? 401, de 1948, bem como o período de férias não gozadas em virtude de achar-se o funcionário requisitado para servir à Justiça Eleitoral, desde que o requeira, segundo o que dispõe o artigo 374 da Lei $n^{\circ} 4.737$, de 15 de julho de 1965 - Código Eleitoral.

(3) Parecer Ref. $n^{9} 63-X$, de 28-6-55, D. O. de 28-7-55.

(4) Parecer no Processo $\mathrm{n}^{0} 9.047-55, D$. O. de 23-4-56. 
- Quer dizer que se o funcionário deixar de gozar licença especial terá o período correspondente contado em dôbro?

- Sim! O funcionário, em cada dez anos de efetivo exercício, tem direito a uma licença especial de seis meses, com todos os direitos e vantagens de seu cargo efetivo. Se não gozou essa licença, poderá contar, em dôbro, para efeito de aposentadoria, o periodo de tempo da licença correspondente a cada decênio. Assim, se um funcionário tem três decênios em que não gozou a licença especial, tem um crédito de trinta e seis meses a ser considerado por ocasião de sua aposentadoria. Se só pode aposentar-se com 35 anos de serviço, com 32 anos, já poderá fazê-lo!

- Se um funcionário acumula um cargo da União com outro estadual, poderá contar o seu tempo em um e outro cargo?

- Sim! Podendo mesmo aposentar-se por ambos, como se fôssem dois funcionários distintos. $O$ que não se pode é contar períodos concorrentes para tempo de serviço, muito menos para determinação de antigüidade de classe... Não se pode, salvo nos rasos de acumulação legal de cargos, computar tempo de serviço concorrente, isto é, aquêle tempo de serviço prestado simultânear mente em mais de um cargo da União, dos Estados, do Distrito Federal, do Município, de Autarquias e de Sociedades de Economia Mista.

- Quer dizer que se um funcionário do Ministério da Justiça tem 20 anos de serviço, não poderá nêle aposentar-se somando êsse tempo com 15 dos 22 que tem como Professor, continuando no exercício do magistério?

- Absolutamente, não! A não ser que reiniciasse a contagem do tempo no magistério: aposentando-se com 35 no Ministério da Justiça e ficando 7 no cargo de Professor...

Há um exemplo interessante: um Desembargador convocado para a Justiça Eleitoral. Poderá êle contar o seu tempo de serviço como servindo no Tribunal de Justiça e também no Tribunai Eleitoral quando exerce concomitantemente as funções de ambos? Evidentemente que não! Sua função no Tribunal Eleitoral se deve à circunstância de ser Desembargador, em razão, assim, de um só cargo.

- Como se comprova a prestação de serviço público?

- Mediante certidão oficial, passada à vista da ficha. de freqüência, da fôlha de pagamento ou até mesmo das anotações das fichas financeiras.

- E se fôr de todo em todo impossivel obter-se tal certidão 
- Excepcionalmente se poderá admitir comprovação por meio de justificação judicial. Em parecer, o Consultor Jurídico do DASP, Dr. Clenício da Silva Duarte, asseverou que "só esgotados todos os meios documentais de comprovação é que se poderá permitir o testemunho de pessoas idôneas." (5)

Já nos detivemos, assim, no exame do tempo de serviço. No âmbito do capítulo dos direitos e vantagens, temos a ajuda de custo, as diárias, o auxílio para diferença de caixa, o salário-familia, o auxilio-doença etc.

Vejamos, agora, a ajuda de custo!

Será essa ajuda concedida ao funcionário que muda de sede, $\mathrm{cm}$ conseqüência de transferência ou remoção "ex officio", nomeação para cargo em comissão, designação para função gratificada e serviço ou estudo no estrangeiro.

Em princípio, a ajuda de custo será concedida ao funcionário que passar a ter exercício em nova ou em outra sede, e se destina à compensação das despesas com a viagem e com a nova instalação... das...

- E essas despesas deverão ser naturalmente comprova-

- Fica a depender da autoridade que tiver competência para conceder a vantagem. (6)

- Que critério deverá ser seguido no arbitramento dessa vantagem?

- A autoridade deverá ter em mente fatôres de vária natureza, como por exemplo as novas condições de vida do funcionário, as despesas de viagem e nova instalação. Nada obstante, não poderá a ajuda de custo ir além da quantia correspondente a três meses de vencimento, salvo se se tratar de viagem ao estrangeiro.

- Quer dizer que não há limitação para a ajuda de custo destinada a funcionário que viaja para o exterior?

- Exatamente! comissão?

- Como se procede nos casos de nomeação para cargo em

(5) Pareceres no D. O. de 30-8-56, p. 16.479, e no de 13-3-57, p. 5.773.

(6) Parecer no Processo $\mathrm{n}^{\circ} 2.010-55, D$. O. de 13-4-55. 
- A ajuda de custo deve basear-se no vencimento do cargo em comissão, e, se se tratar de designação para função gratificada, deve basear-se no valor do símbolo da função gratificada. viajar?

- O funcionário receberá a vantagem antes ou depois de

- É-lhe facultado receber a ajuda de custo na nova sede.

- Há casos em que essa vantagem não será concedida?

- Sim! Em três casos: ao funcionário que, em virtude de mandato eletivo, deixar o exercício do cargo ou reassumi-lo; ao funcionário pôsto à disposição de qualquer entidade de direito público, e quando fôr, o funcionário, transferido ou removido a pedido.

- E no caso de permuta?

- Também não será concedida a vantagem.

- Se o funcionário fôr obrigado a permanecer fora da sede da sua repartição por mais de trinta dias, perceberá ajuda de custo?

- Se em objeto de serviço, desde que o deslocamento seja ocasional e não decorra do exercício normal do cargo, sim, e no valor eqüivalente a um mês de vencimento.

- Se por acaso não se transportar o funcionário para a nova sede no prazo que the fôr marcado e já havendo êle recebido a ajuda de custo...

- Deverá restituir integralmente a vantagem recebida! O mesmo acontecendo se regressar, pedir exoneração ou abandonar o serviço antes de terminada a missão ou incumbência!

- Mas poderá acontecer que o funcionário seja compelido a voltar por motivo alheio à sua vontade, sem cumprir a tarefa...

- Sim, principalmente se houver determinação da autoridade competente ou em razão de doença comprovada! Aî, a restituição não se dará! É de notar que não haverá, ainda, restituição se o funcionário exonerar-se após noventa dias de exercício na nova
sede.

- A restituição poderá ser feita parceladamente?

- Sim, a critério da autoridade competente. Nunca, porém, em caso de desvinculamento do serviço püblico! faz?

-- E se o funcionário tem mulher, filhos, bagagens... Como 
- O transporte é custeado pela própria Administração, tendo o funcionário direito a levar sua familia, inclusive um serviçal. O transporte compreende passagem e bagagem, embora a despesa quanto à bagagem não possa exceder a $25 \%$ da ajuda de custo.

Vejamos, a seguir, as diárias!

Já vimos que, quando o funcionário se desloca em caráter permanente ou por mais de trinta dias, terá êle direito a um tipo de vantagem, que é a ajuda de custo! Quando ếsse deslocamento fôr ocasional, eventual, para cumprir uma missão, uma tarefa, terá o funcionário direito à percepção de diárias para alımentação e pousada. Diz o Estatuto dos Funcionários, em seu artigo 135: "Ao funcionário que se deslocar da sua repartição em objeto de serviço conceder-se-á uma diária a título de indenização das despesas de alimentação e pousada."

- Até mesmo no período de trânsito?

- Não! É taxativo o Estatuto quando estabelece que não se há de conceder diária durante o periodo de trânsito, tampouco quando o deslocamento constituir exigência permanente do cargo ou função!

- Conceder-se-ão diárias a funcionário que, eventualmente, tem exercício no exterior?

- Durante o período de afastamento do nosso País?

- Sim!

- Não serão concedidas, salvo se se encontrar em missão de caráter permanente no exterior e fôr compelido a deslocar-se da sede em objeto de serviço, dentro do país em que estiver servindo ou fora dêle.

- Qual o critério de fixação das diárias?

- Reza o artigo 136 do Estatuto dos Funcionários que “o arbitramento das diárias consultará a natureza, o local e as condições de serviço, respondendo o chefe da repartição pelos abusos cometidos." Regra prática em vigor é a de que cada diária não poderá ser inferior a dez por cento do salário-mínimo vigente na localidade para onde se afastar o funcionário, nem superior a trinta por cento. É, assim, de dez a trinta por cento do saláriomínimo da região para onde vai o funcionário.

- Não há diferença entre o funcionário comum e o que exerce chefias?

- Há! No caso de ocupante de cargo em comissão ou de função gratificada, cujo valor do simbolo seja superior ao do 
maior nivel de vencimento, a diária poderá ser igual a trinta e cinco por cento do salário-mínimo em vigor na localidade para onde vai o funcionário.

- A diária é sempre integral?

- Não! Só é integral quando o funcionário passar mais de doze horas fora da sede. Será meia diária, quando passar de sete a doze horas fora da sede.

- Que se entende por "sede da repartição"?

- De conformidade com a definição dada pelo Decreto número 50.524 , de 3 de maio de 1961, alterado pelo Decreto número 52.388 , de 20 de julho de 1963 , que regulamentou a concessão das diárias, "sede da repartição", para efeito dêste Regulamento, é a cidade ou localidade onde o servidor tem exercício. funcionário"?

- Pode-se distinguir entre "sede da repartição" de "sede do

- Sim. Consoante parecer do Consultor-Geral da República, a "sede da repartição" centraliza as atividades de cúpula do órgão, vale dizer, onde a sua diretoria exerce o poder de administrar e, quase sempre, é determinada na lei que cria a repartição. A "sede do funcionário" é sempre o local onde presta o serviço, isto é, onde tem exercício. (7)

- Na concessão das diárias, levar -se-á em conta o quê?

- A natureza, o local e as condições de serviço...

- Não se levará em conta existência de saldo na verba? mitação.

- O arbitramento das diárias não depende mais dessa li-

- Mas há critérios gerais de fixação?

- Sim, já vimos: não poderá ser inferior a dez por cento do salário-minimo vigente na cidade para onde se afastar o funcionário, nem superior a trinta por cento do mesmo salário-mínimo.

- E nos casos de ocupantes de cargos em comissão ou dt funções gratificadas, cujo valor de símbolo seja superior ao da referência-base de maior nivel de vencimento, que o do nivel vinte

- Neste caso, a diária poderá ser igual a trinta e cinco por cento do salário mínimo vigente no local para onde se afastar $c$

(7) Parecer $\mathrm{n}^{\circ} 30$, de $17-6-64, D$. O. de 22-4-64. 
- Conceder-se-á diária ou meia diária a um funcionário com sede no antigo Distrito Federal, atual Estado da Guanabara, quando designado para prestar serviços dentro da área daquele Estado ou em localidades como Caxias, Niterói, Petrópolis, Nova Iguaçu?

- Não se justifica a concessão, tanto de diária como de meia diária, nesses casos, conforme já esclareceu o DASP em parecer exarado no Processo $n^{\circ}$ 6.297, de 1946, publicado no Diário Oficial de 4 de outubro de 1946. Ainda está em vigor ésse entendimento, sendo de ressaltar que a alusão ali feita ao antigo Distrito Federal é exemplificativo. O princípio se aplica à prestação de serviço em quaisquer áreas próximas à sede onde serve o funcionário.

- É o mesmo o regime de concessão de diárias quanto aos servidores diplomáticos e consulares?

- Não! De acôrdo com o que dispõe o artigo 13 do Decreto $\mathrm{n}^{4}$ 50.524, de 3 de maio de 1961, a concessão de diárias àqueles servidores continuará a processar-se na forma de legislação especifica que a regula.

- E quanto aos servidores com exercício em Brasília?

- Consoante o que dispõe o artigo 14 do Decreto n $n^{\circ} 50.524$, de 3 de maio de 1961, a concessão de diária, devida aos servidores, continuará a processar-se na forma da legislação específica que a regula.

- Que legislação disciplina as diárias de Brasília?

- A Lei $n^{\circ} 4.019$, de 20 de dezembro de 1961, que complementou o artigo $6^{\circ}$ da Emenda Constitucional n ${ }^{\circ} 3$. E regulada pelo Decreto $\mathrm{n}^{\circ} 807$, de 30 de março de 1962. O artigo 13 da Lei $n^{\circ} 4.345$, de 26 de junho de 1964, dispôs sôbre o assunto, limitando o pagamento das diárias, e essa limitação foi regula mentada pelo Decreto $n^{\circ} 54.012$, de 10 de julho de 1964 , alterado pelo de $\mathrm{n}^{\circ} 54.352$, de 29 de setembro de 1964 .

- Há possibilidade de acumulação de diárias de Brasilia com as previstás no Estatuto?

- De acôrdo com o pensamento do Consultor Jurídico do DASP, Dr. Clenício da Silva Duarte, externado em parecer aprovado pelo Diretor-Geral daquele Departamento, quando o funcionário tiver de se afastar de Brasília por prazo igual ou inferior a trinta dias, ser-lhe-á facultado optar pelas diárias com prejuizo das diárias de Brasília. (8)

(8) Parecer no Processo $\mathrm{n}^{9} 4.766-64, D$. O. de 27-7-64. 
- Como se processará a concessão da diária estatutária?

- A concessão será proposta ao órgão de pessoal pelo Chete da Repartição ou Serviço, que indicará o nome do funcionário, cargo ocupado, local para onde se afasta, natureza do serviço a ser executado, tempo provável do afastamento e número de diárias a serem adiantadas. Em seguida, após examinar a legalidade e conveniência da despesa, o órgão de pessoal arbitrará e concederá as diárias, considerando as indicações feitas pelo chefe da repartição em que o funcionário tem exercício, diligenciando o respectivo pagamento através de fôlha avulsa a ser publicada no órgão oficial.

- E nas localidades em que não houver órgão de pessoa!, como será organizada a fôlha de diárias?

- Será organizada pela própria repartição ou serviço a que pertencer o servidor, cabendo ao respectivo chefe arbitrar a importância das diárias e autorizar o pagamento. Nesse caso, a segunda via da fôlha deverá ser remetida ao órgão de pessoai para publicação e contrôle.

\section{III}

$\mathrm{O}$ artigo 137 do Estatuto dos Funcionários assim dispõe:

"Ao funcionário que no desempenho de suas atribuições pagar ou receber em moeda corrente, poderá ser concedido auxílio fixado em cinco por cento do padrão do vencimento para compensar diferenças de caixa".

Posteriormente, o auxílio passou a ser de dez por cento dos vencimentos recebidos pelos Tesoureiros e Tesoureiros-Auxiliares, de acôrdo com a Lei n' 4.061, de 8 de maio de 1962 .

A concessão dêsse auxílio foi regulamentada pelo Decreto n? 34.406, de 29 de outubro de 1953, alterado pelo Decreto número 35.056 , de 5 de agôsto de 1954 . em geral?

- Êsse benefício se refere a funcionário que paga ou recebe,

- Refere-se aos Tesoureiros e Tesoureiros-Auxiliares que, no desempenho de suas atribuiçóes, pagarem ou receberem em
moeda corrente.

- Qual o critério de pagamento?

- O auxílio será uniforme, concedido por fôrça do que dispõe o artigo 10 da Lei $n^{\circ} 4.863$, de 1965 , na base de trinta 
por cento do padrão de vencimento, independentemente da existência de diferença de caixa. Cumpre notar que essa vantagem sòmente será paga ao funcionário que se encontre em efetivo exercicio de suas funções de pagador ou de recebedor, inclusive durante os periodos de férias, desde que, naquelas funções, haja tido exercício durante os onze meses anteriores.

- Quer dizer que, cessada a atividade de pagar ou receber em moeda corrente, em razão de qualquer afastamento, salvo férias, haverá interrupção no pagamento da vantagem?

- Exatamente!

- Estende-se o auxílio para diferença de caixa a algum outro servidor?

- Sim. Aos servidores das Coletorias Federais que tiverem sob sua guarda a caixa dessas repartições e das Agências de Arrecadação; aos Fiéis de Tesoureiro do Ministério da Aeronáutica; aos Cobradores do Departamento de Imprensa Nacional, bem como aos Fiéis de Agência do Departamento dos Correios e Telégrafos.

- Há necessidade de requerimento para obtenção do auxílio?

- Não! Deverá ser processado pelas próprias repartições em que servem seus destinatários específicos.

- Fará jus ao auxílio para diferença de caixa funcionárı que recebe adiantamento?

- Não! O adiantamento pode ser consignado a qualquer servidor, sem que isso implique em reconhecer direito à percepção do auxílio. Só se concede o auxílio para diferença de caixa àqueles funcionários que se encontrem no efetivo exercício, desempenhando como atribuições normais os encargos de pagar ou receber em moeda corrente.

- E o Administrador de Mesas de Renda?

- Também não! rente!?

- E para o Almoxarife que paga e recebe em moeda cor-

- Só se estiver desviado de função a merecer uma readaptação na forma da Lei $\mathrm{n}^{\circ} 3.780$, de 12 de julho de 1960 e legislação complementar. Se isto ocorre, só depois de readaptado! Antes, não!

Veremos, agora, outra vantagem pecuniária que tem o nome de auxilio-doença.

- Quando terá cabimento êsse benefício? 
- O funcionário terá direito a um mês de vencimento ou remuneração após doze meses consecutivos de licença para tratamento de saúde, em conseqüência das doenças arroladas no artigo 104 do Estatuto dos Funcionários: tuberculose, alienação mental etc.

- Como se processará?

- A concessão e o processamento dessa vantagem estão disciplinadas no artigo 146 do Estatuto dos Funcionários, regulamentado pelo Decreto $n^{\circ} 33.634$, de 21 de agôsto de 1953.

- A partir de quando deve ser autorizado o pagamento do auxílio-doença?

- Mercê de sua finalidade assistencial, deve o seu pagamento ser autorizado a partir do dia imediato àquele em que o funcionário completar o periodo de doze meses consecutivos de licença para tratamento de saúde. xilio-doença?

- Quais as autoridades competentes para conceder o au-

- As mesmas que vêm concedendo licença por motivo das doenças especificadas no artigo 104 do Estatuto, a que já nos referimos. Isto, para facilitar o processamento de concessão do auxilio. De modo geral, quem concede são os dirigentes do órgão
de pessoal.

- Se, após o decurso dos doze meses, vier a falecer o funcionário, a quem será pago o benefício?

- À família dêle, de conformidade com as normas que regulam o pagamento de vencimentos não recebidos. Veja-se o artigo 5: do Decreto $n^{\circ} 33.634$, de 21 de agôsto de 1953.

- A gratificação adicional se inclui no vencimento do interessado para efeito de auxilio-doença?

- Não! E já existe parecer do DASP nesse sentido! Veja-se parecer no Processo n? 10.608 , de 1956 , publicado no Diário Oficial de 24 de novembro de 1957, páginas 1.706. A Lei número 4.345 , de 28 de junho de 1964 , no parágrafo $5^{\circ}$, do artigo 10 , determina que sôbre essa gratificação de tempo de serviço não poderão incidir quaisquer vantagens pecuniárias.

- Por conta de quem correrá o tratamento do funcionário acidentado em serviço?

- Por conta dos cofres públicos ou de instituição de assistência social, mediante acôrdo com a União.

Cuidemos, agora, das gratificações! 
São elas acréscimos pecuniários ao que o funcionário normalmente percebe, e decorrem de previsão legal.

O Estatuto dos Funcionários, em seu artigo 145, prevê vários tipos de gratificação: gratificação de função; gratificação pelo exercício do magistério; gratificação pela prestação de serviço extraordinário; gratificação pela representação de gabinete; grati. ficação pelo exercício em determinadas zonas ou locais; gratificação pela execução de trabalho técnico ou científico; gratificação pela execução de trabalho de natureza especial, com risco de vida ou saúde; gratificação por serviço ou estudo no estrangeiro; gratificação pela participação em órgão de deliberação coletiva; gratificação pelo exercício do encargo de auxiliar ou membro de banca e comissões de concurso, ou de encargo de auxiliar ou professor em curso legalmente instituído e, finalmente, gratificação adicional por tempo de serviço.

Vejamos cada uma de per si! Gratificação de função! Se: gundo o Estatuto dos Funcionários, é a que corresponde a encargo de chefia e outros que a lei determinar. Ou mais explicitamente: é a que se atribui ao funcionário efetivo em virtude de função gratificada, com o objetivo de recompensá-lo pelos encargos e responsabilidades provenientes de função de chefia, de as sessoramento, ou de secretariado.

- Parece certo que não constitui emprêgo!

- Certamente! Trata-se de vantagem accessória, criada por ato do Poder Executivo, desde que haja recurso orçamentário próprio e sido prevista no regimento da repartição a que se destina.

- Deve haver um critério para a classificação!

- Sim! Há princípios básicos para se regulamentar a classificação das funções gratificadas: hierarquia funcional, analogia das funções, e importância, vulto e complexidade das respectivas atribuiçőes.

- Que mais é necessário nessa regulamentação?

- Prever a correlação fundamental entre as atribuições do cargo efetivo ocupado pelo funcionário e as da função gratificada para que fôr designado.

- Não se pode, então, criar função gratificada por portaria?

- Exatamente! Só mediante decreto e com previsão regimental! Para sua criação, é essencial estejam previstos, no $\mathrm{Re}$ gimento da repartição, a que se destina, os encargos de chefia, assessoramento ou secretariado; que existam recursos orçamen- 
tários próprios e que não constitua emprêgo e, sim, como dissemos, vantagem accessória ao vencimento ou salário, e restrita ao serviço público. tificada?

- Funcionário interino pode ser designado para função gra.

- Não! Já dissemos que função gratificada é a que se atri. bui ao funcionário efetivo...

Vejamos, agora, a gratificação pelo exercicio de magistério!

Era ela devida, de início, aos ocupantes de cargo de Professor Catedrático. Depois, mercê de leis especiais, foi essa gratificação estendida a outros membros do magistério federal.

A Lei $n^{\circ} 4.345$, de 26 de junho de 1964, em seu artigo 15, revogou essa gratificação, bem como as que se referem à execução de trabalho técnico ou cientifico, de trabalho de natureza especial com risco de vida ou saúde, a de nível universitário, a de representação prevista no artigo 29 da Lei $n^{\circ} 4.242$, de 17 de julho de 1963, e ao abono de permanência na atividade.

locais?

- E a gratificação pelo exercicio em determinadas zonas ou

- Essas zonas e locais estão sendo determinadas em regulamento. O assunto depende, assim, de regulamentação, cujo projeto já se encontra na Presidência da República.

- Há alguma previsão?

- A gratificação deverá variar entre vinte e quarenta por cento do vencimento do cargo efetivo do funcionário.

- O que restou das gratificações?

- A gratificação pela prestação de serviço extraordinário; a gratificação pela representação de gabinete; a gratificação pelo exercício em determinadas zonas ou locais, em vias de ser regulamentada; a gratificação por serviço ou estudo no estrangeiro; a gratificação pela participação em órgão de deliberação coletiva; a gratificação pelo exercício do encargo de auxiliar ou membro de banca e comissões de concurso, ou de encargo de auxiliar de professor em curso legalmente instituido, e, finalmente, a gratificação adicional por tempo de serviço. Há, ainda, a gratificação por hora de vôo e a gratificação de tempo integral e dedicaçãó
exclusiva.

Consideremos a gratificação pela prestação de serviço extraordinário!

- $\mathrm{O}$ que se executa além do expediente normal? 
- Sim. Como se sabe, o horário normal de trabalho é de trinta e duas horas e meia semanais, de modo geral. Os ocupantes de cargos de nivel universitário estão sujeitos a trinta horas semanais de trabalho. Aquêles que executam serviços de vigilância, trabalho braçal, de motorista etc. estão sujeitos a duzentas horas mensais. Pois bem! Tais horários podem ser antecipados ou prorrogados, no interêsse exclusivo do serviço, de acôrdo com as suas reais necessidades, e a critério do chefe da repartição.

- E receberá o funcionário, por essa antecipação ou por essa prorrogação, uma gratificação...

- Efetivamente! Terá o funcionário direito a perceber uma gratificação pelo trabalho extraordinário que realizar... direito?

- Quer dizer que se não realizar trabalho algum não terâ

- Não é bem assim! Há uma presunção de que a pror roggaçăo ou antecipação do expediente foi no interêsse do Serviço para atender a uma emergência, a uma necessidade imediata... Autorizada a prorrogação ou antecipação, é de presumir que o trabalho extraordinário passou a ser executado! Mas o funcionário passará a ter direito à gratificação, quer o trabalho tenha, ou não, sido realizado, desde que, nesta última hipótese, não o seja por culpa sua.

\section{- Há critério para êsse pagamentol}

- Sim! A gratificação poderá ser arbitrada prèviamente pelo chefe da repartição, desde que não ultrapasse a um têrço do venrimento ou remuneração do funcionário. Poderá ser, também, paga por hora de trabalho, prorrogada ou antecipada...

- Neste caso, há também limitação?

- Exatamente! Em hipótese alguma, poderá exceder a um têrço do vencimento ou remuneração diária! Quando o trabalho fôr prestado à noite, o valor da hora extraordinária será acrescida de vinte e cinco por cento.

- Se a prorrogação ou antecipação é para atender a uma necessidade imediata, a uma emergência, tem um limite na sua duração...

- Com efeito! Não faz sentido se faça trabalho extraordinário por tempo indeterminado. Em cada ano civil, a duração é de sessenta dias consecutivos ou cento e vinte dias intercalaw dos...

- Mas, a repartição pode necessitar dias a fio dos serviços de um motorista... 
- Cada motorista está sujeito a duzentas horas mensais. A repartição deve fazer escala de trabalho, dividir o serviço, compensar alguma hora a mais...

\section{IV}

Continuemos a dialogar sôbre o capitulo dos direitos e vati. tagens do funcionário! Cuidemos, agora, da gratificação pela representação de Gabinete!

- A que se destina?

- A indenizar, pelas despesas extras a que estão suscetiveis, aquẻles que servem em Gabinete da Presidência da República e de Ministro de Estado, bem como em Gabinete ou Secretaria- Geral de órgão de assessoramento do Presidente da República, em Gabinete do Diretor -Geral da Fazenda Nacional ou, de modo excepcional, por necessidade imperiosa do serviço, à vista de proposta do Ministro de Estado, aos que servem em outros órgãos da Administração Federal Direta ou Indireta. Ao que não tem vinculo com a Administração Federal e ao que tem êsse vínculo.

- Há algum critério para pagamento dessa gratificação?

- Haverá tabela própria. Cada um dos gabinetes terá previstos em tabelas os encargos, com as denominações e gratifica ções respectivas.

- Quem aprovará essa tabela?

- O Presidente da República, após estudo e parecer conrlusivo do DASP, que terá o prazo de trinta dias para elaborar - pronunciamento e submeter a matéria à decisão presidencial.

- Há modêlo para tais tabelas?

- Há uma Tabela-Padrão, constante do Decreto n 59.835 , de 21 de dezembro de 1966, alterada pelo Decreto $n^{\circ} 61.049$. de 21 de julho de 1967, publicada no Diário Oficial do dia 24 seguinte.

- E a tabela, assim elaborada, que deverá conter?

-- Conterá, obrigatòriamente, as quantidades e denominaç̃es dos encargos dispostos em ordem decrescente, observados a hierarquia, a responsabilidade e grau de complexidade, tanto quanto o cálculo da despesa que acarretará ao órgão e a indicacão da existência de recursos suficientes e adequados a seu aten-
dimento.

- A tabela vale por um ano!? 
- Vigorará por tempo indeterminado, podendo, entanto, ser revista na medida da necessidade do Serviço. Deverá a tabela, ainda, ser reajustada na hipótese de redução na rubrica orçamentária própria.

- Mas êsse reajustamento é facultativo!

- Não! Quando houver redução na rubrica orçamentária própria, será a tabela obrigatòriamente reajustada!

- Após aprovada a tabela pelo Presidente da República e publicada no Diário Oficial, como se deverá proceder?

- Caberá ao Ministro de Estado, ao dirigente do órgão diretamente subordinado ao Presidente da República ou da Autarquia ou da repartição baixar os atos de designação, que podem ser individuais ou coletivos.

- E a que autoridade compete dispensar?

- Os atos de dispensa são da competência das mesmas autoridades legalmente competentes para designar.

- Tais atos são divulgados no Diário Oficial?

- Exatamente! As tabelas e as portarias de designação ou dispensa só terão valimento se publicadas no Diário Oficial! Só a partir dessa publicação no órgão oficial é que os atos passam a surtir seus efeitos, inclusive o direito à percepção da respectiva gratificação.

- A gratificação pela representação de Gabinete será paga com base na freqüência, ou em quê?

- Com base na freqüência, salvo - com referência aos que têm vínculo com a Administração Federal - nos casos de férias, de gala, de nojo, de licença para tratamento de saúde. de licença à gestante e serviço obrigatório por lei, como participação em Júri.

- Se um funcionário estiver percebendo gratificação de representação de Gabinete e fôr cursar a Escola Superior de Guerra, poderá continuar auferindo essa gratificação por todo o tempo em que estiver fazendo aquêle curso?

- Não! Essa gratificação é especial e paga com base na freqüência, já o dissemos...

- Mas a Lei que criou a Escola Superior de Guerra determinou fôsse considerado como de efetivo exercício, para todos os efeitos, o periodo em que o funcionário civil estiver à dispo. sição daquela Escola em funções administrativas ou de ensino, ou quando alunos. .. 
- Com efeito, o artigo 9' da Lei $\mathrm{n}^{\circ} 785$, de 20 de agôsto de 1949, diz isso! Mas a Administração, ao interpretar o dispositivo, já entendeu que aquela expressão deve ser entendida em seus devidos têrmos. Já existe, aliás, parecer do DASP nesse sentido, em que se argumentou que a circunstância de determinar a Lei fôsse considerado como de efetivo exercício, para todos os efeitos, o período de afastamento para o funcionário, por exemplo, cursar aquela Escola como aluno não chega ao ponto de permitir se afirme esteja implicito também no preceito a continuação do pagamento da gratificação de representação de Gabinete, porquanto esta gratificacão sòmente se justifica pela real prestação de serviço em Gabinete, segundo se infere de sua própria denominação.

Aduziu, ainda, o DASP que, a ser deferida tal pretensão, seria o caso, também, de não haver interrupção da percepção dessa vantagem por parte do servidor que já a tivesse e que viesse a entrar em gôzo de licença prêmio, cujo periodo de tempo, igualmente, como se sabe, é considerado como de efetivo exer. cício. (9)

- De quando será mesmo devida essa gratificação pela representação de Gabinete?

- Será devida a partir da data da publicação da respectiva portaria de designação.

- Será ela incorporada ao vencimento?

- Não! Para nenhum efeito!

- Qual o horário a que fica sujeito quem perceber gratificação pela representação de Gabinete?

- A percepção dessa gratificação obriga o funcionário su mesmo quem não fôr funcionário a prestar, no mínimo, quarenta horas semanais de trabalho...

- Quer dizer que êsse periodo de quarenta horas semanais poderá ser, ainda, elevado?

- Sim! Quando houver conveniência e interêsse do Serviço.

- Poderá ser recebida cumulativamente a gratificação pela representação de Gabinete com retribuição de cargo em comissão ou função gratificada?

- Não! Essas retribuições são incompativeis. Cumpre observar que, em todos os casos, se aplica o teto máximo legal de

(9) Parecer do Consultor Juridico do DASP, Dr. Luiz Rodrigues, no
cesso $\mathrm{n}^{\circ}$ 12.043-65. Não publicado. 
retribuição. Tirante o teto, essa norma não se aplica aos ocupantes de cargos em comissão ou de função gratificada da Presidência da República. (10)

Já tivemos oportunidade de dizer que a gratificação pelo exercício em determinadas zonas ou locais será determinada em regulamento ainda não baixado pelo Poder Executivo, mas em vias de ser decretada. Está prevista no artigo 14 da Lei número 4.863 , de 1965 , sendo que o seu valor variará entre vinte e quarenta por cento do vencimento do cargo efetivo ocupado pelo funcionário sujeito a êsse regime de trabalho.

Passemos, então, ao exame da gratificação por serviço on estudo no estrangeiro!

- Qual a finalidade dessa vantagem?

- E proporcionar, aos servidores mandados servir ou estudar no exterior, meios de vida condignos com sua qualidade de servidor público, compensando os desniveis de câmbio porventura existentes.

- Naturalmente deve haver critérios rígidos para a concessão dessa vantagem!

- Há critérios, porém não rígidos! É livremente arbitrada essa vantagem pelo Presidente da República em cada caso concreto.

- Não está délegada a competência?...

- Só está delegada a concessão de licença para afastamento do país, sem ônus para os cofres públicos! Logo, é do Presidente da República a competência para arbitrar a vantagem!

Examinemos, a seguir, outro tipo de gratificação - a que se atribui pela participação em órgão de deliberação coletiva.

Essa gratificação, como o nome está a dizer, é a que se paga por sessão a que comparecerem os membros de órgãos colegiados. Não poderá ir além da importância correspondente ao número máximo de sessões ordinárias previsto nos atos de classificação daqueles órgãos.

- Também êsses órgãos são classificados?

- Sim. Estão classificados nas categorias A, B, C e D, em obediência ao princípio de hierarquia, da analogia ou eqüivalên. cia de funções, levando-se em linha de conta, ainda, a impor-

(10) Veja-se o-Decreto $n^{\circ} 59.835$, de 21-12-1966, que dispõe sôbre a concessão de gratificação pela representação de Gabinete, com as respectivas tabelas e alterações feitas pelo Decreto $\mathrm{n}^{2}$ 61.049, de 21-7-1967. 
tância, o vulto e a complexidade das respectivas atribuições e responsabilidades, nos têrmos das normas constantes do Decreto n? 55.090, de 28 de novembro de 1964, publicado no Diário Oficial de 2 de dezembro dêsse mesmo ano. O sistema preconizado na Lei n? 4.242, de 17 de julho de 1963, não tem impedido que subrepticiamente se estejam criando novos órgãos fora do critério geral e uniforme, naturalmente com vantagens a título de jetton muito acima do máximo percentual fixado pelo Decreto $n^{2} 55.090$, de 26 de novembro de 1964.

- Qual o percentual atribuído normalmente?

- Trinta por cento sôbre o nivel 1 ao órgão da categoria A. Vinte e cinco por cento sôbre o nivel 1 ao órgão da cate goria B. Vinte por cento sôbre o nível 1 ao órgão da categoria C. Quinze por cento sôbre o nível 1 ao órgão da categoria D.

- Quer dizer que a percentagem não é calculada sôbre o salário-mínimo?

- Não! E calculada sôbre o vencimento correspondente ao nivel 1. E o órgão que estiver pagando dentro de critério dife. rente está pagando mal...

- O presidente do colegiado só percebe o jetton?

- Não! A gratificação do presidente do colegiado corresponderá, por sessão, à importância própria à categoria do órgão a que pertence, acrescida de trinta por cento de seu valor, não fazendo jus, todavia, à representação mensal fixa ou a outra vantagem eqüivalente.

- Quanto percebe o funcionário que exerça as atividades de secretário de órgão de deliberação coletiva?

- A êsse funcionário será atribuída gratificação eqüivalente à metade da importância a que fizerem jus os respectivos membros. Deixará de ser paga essa vantagem quando as atividades de secretário correspondam ou venham a corresponder a cargo em comissão ou a função gratificada. A nosso ver, é falho o critério quando é êle aplicado ao Secretário pois que êste, como tal, tem função de caráter permanente e não pode receber por sessão a que comparece.

Cuidemos, agora, da gratificação pelo exercicio do encargo de auxiliar ou membro de banca e comissões de concurso, ou a gratificação pelo encargo de auxiliar ou professor de cursos legal-
mente instituidos.

- Quando serão pagas? 
- Tais encargos sòmente serão remunerados quando executados fora do periodo normal ou extraordinário de trabalho, a que estiver sujeito o funcionário, em razão de seu cargo.

- Há, ainda, a gratificação adicional por tempo de serviço!

- Sim, se se trata de verdadeiro acréscimo de vencimento, à base de serviços prestados durante longo periodo de atividade funcional.

Cumpre esclarecer que, de acôrdo com o disposto no art. 146 do Estatuto dos Funcionários Públicos Civis da União, ao funcionário que completasse vinte anos de serviço público efetivo era atribuida uma gratificação igual a quinze por cento do respectivo vencimento, gratificação essa que seria elevada a vinte $e$ cinco por cento quando o tempo de serviço fôsse de vinte e cinco anos completos. Com o advento da Lei $n^{\circ} 4.345$, de 28 de junho de 1964, essa gratificação passou a ser concedida na base de cinco por cento por qüinqüênio de efetivo exercício, até sete qüinqüênios. Pode ser chamada também, gratificação de tempo de serviço ou gratificação qüinqüenal.

- De quando é devida?

- O direito a essa gratificação qüinqüenal começa no dia imediato àquele em que o funcionário completou o qüinqüenio e será calculada sôbre o vencimento do cargo efetivo.

- Qual o percentual da gratificação?

- Para cinco anos de efetivo exercício, cinco por cento calculados sôbre o vencimento do cargo efetivo. Para dez anos, dez por cento. Para quinze anos, quinze por cento. Para vinte anos. vinte por cento. Para vinte e cinco anos, vinte e cinco por cento. Para trinta anos, trinta por cento. Para trinta e cinco anos, trinta e cinco por cento.

- Qual o critério para cálculo dessa gratificação a ser paga a funcionário sujeito a regime especial de remuneração? efetivo que ocupar.

- Será calculada na base do padrão de vencimento do cargo

- E o investido em cargo em comissão?

- Continuará a perceber a gratificação adicional na base do vencimento do cargo efetivo...

- Não se calcula sôbre o valor do cargo em comissão?

- Não! O órgão que pagar assim está pagando mal!

- E se o funcionário fica em disponibilidade ou se aposenta? 
- Continuará a auferir a gratificação adicional na base percebida na atividade. Nesse caso, a gratificação será fixa, não variando por fôrça das oscilações decorrentes de cálculo dos pro ventos.

- E se o funcionário deixar de perceber o vencimento em virtude de licença, suspensão ou outro afastamento ou ausência ao serviç̧o?

- Não lhe será paga a gratificação adicional enquanto deixar de perceber o vencimento por qualquer daqueles motivos.

- Poderá, sôbre a gratificação adicional, incidir alguma vantagem pecuniária?

- Não! Nenhuma!

Finalizando, veremos a gratificação por hora de vôo! É a que se concede aos pilotos civis da União e das Autarquias Federais. Corresponde a um por cento do vencimento, por hora de vôo, sem que possa ser ultrapassado de dois têrços. Trata-se de uma inovação trazida pela Lei nò 4.069 , de 11 de junho de 1962.

Corsíndio Monteiro da Silva - Assistente Juridico do DASP, Membro da Comissão de Acumulação de Cargos (CAC). 